\title{
THE CHEMICAL AND MORPHOLOGICAL PROPERTIES OF OLEASTER
}

\author{
Mehmet Akgüll, Mehmet Akça,
}

\begin{abstract}
This study investigated the morphological characteristics and chemical properties of the wood and the chemical properties of the bark of the oleaster (Elaeagnus angustifolia) tree, which grows in a variety of climatic conditions in different regions of Turkey. The study materials were taken from three different regions of Turkey having different climatic conditions and elevations with the aim to determine the chemical properties of the bark and wood and the fiber properties of the wood. According to chemical analyses, no significant differences in the core components of the cell wall were observed between the heartwood and the sapwood. The samples collected from the Çankiri region had the highest holocellulose content $(84,9 \%)$, while the proportions of alpha cellulose $(52,3 \%)$ and lignin $(24,0 \%)$ in samples taken from the Balikesir region were found to be higher than in samples from the other regions. According to the sugar analysis, glucose and xylose were found to be higher in the heartwood than in the sapwood. When the sugar ratios were evaluated by region, the glucose and xylose ratios were the highest in the Çankiri region $(43,7 \%$ and $22,8 \%)$ and the lowest in the Konya region (38,3\% and 20,5\%). When looking at the inner bark (phloem) and outer bark (rhylidome) rates, the amounts of holocellulose and alpha cellulose were higher in the inner bark and the lignin rates were higher in the outer bark. The wood solubility values for cold and hot water, ethyl alcohol and the $1 \% \mathrm{NaOH}$ were highest in samples from the Çankiri region and lowest in those from the Konya region, whereas bark solubility rates were highest in the samples taken from the Balikesir region. When morphological characteristics were examined, no obvious differences were seen among the regions in terms of the fiber length, fiber width, lumen diameter or double wall thickness. Upon further investigation, it was determined that the oleaster tree wood was suitable for papermaking, but that the produced paper would exhibit a low resistance value because the average felting rate among the three growing regions was low $(39,87 \%)$.
\end{abstract}

Keywords: Elaeagnus angustifolia, heartwood, inner bark, morphological characteristics, outer bark, phloem, rhylidome, sapwood.

\section{INTRODUCTION}

The oleaster tree (Elaeagnus angustifolia) has served humanity since ancient times. It has been used for wood, food, shelter, hand tools and utensils. In parallel with the increasing progress of industrialization, technology is expanding day by day, and the use of wood materials in the timber, furniture and wood panel industries has expanded by incorporating different forms of wood materials. As a result of the recent increase in demand for renewable alternative sources in addition to the traditional utilization of wood, such as in the furniture and timber industries, lignocellulosic materials from wood are emerging to the forefront in a variety of applications in fields like chemical production, pharmacology, cosmetics and the food industry.

The forest products industry has shown less interest in bark than in wood. Despite this, bark has begun to gain importance and is already being used in tanning leather, as a fuel to supply energy (Biermann 1993,

\footnotetext{
${ }^{1}$ Necmettin Erbakan University, S. Ahmet Cengiz Engineering Faculty, Department of Materials and Metallurgical Engineering, Seydişehir, Konya, Turkey.

${ }^{2}$ Balikesir University, Dursunbey Vocational School, Forestry and Forest Products Programme, Balikesir, Turkey.

•Corresponding author: akcamehmet10@gmail.com

Received: 04.04.2017 Accepted: 11.09.2019
} 
Karonen et al. 2004, Cadania et al. 2001, Cunha-Queda et al. 2007), as a raw material in the manufacture of adhesives and as compost in agricultural production. Although new chemical components are constantly being discovered, studies on bark are less common than those on wood. Nowadays, in paper production and other industrial branches using wood products, the bark is considered as a major waste and cause of environmental pollution. However, as well as being a source of energy, the bark of many plant species contains chemicals rich in bioactive and antioxidant properties (Kähkonen et al. 1999, Pietta 2000, Tan et al. 2003, Wilför et al. 2003).

The oleaster tree (Elaeagnus angustifolia) is a species of leafy tree that can grow in different regions of our country and in different climatic conditions (Figure 1). In Turkey, this fruit-bearing species with fragrant flowers is used as a landscape tree in parks and gardens. However, there have been no studies conducted on the characteristics of the wood and bark of the oleaster tree to date, which indicates a significant deficiency in the literature.

The trunk is $5-12 \mathrm{~m}$ in height and $10-50 \mathrm{~cm}$ in diameter. Thanks to the ability of the oleaster to store nitrogen in its roots, it can grow even in the poorest of soils. In addition, due to its drought tolerance, the oleaster is also used to combat erosion in many countries (Anonymous 2007). It is also a popular ornamental plant in Europe and America because it has fewer disease and insect problems (Peterson 1976, Carrol et al. 1976, Krupinsky and Frank 1986).

The tree grows in almost every region of Turkey, especially in Central and Eastern Anatolia. According to TURKSTAT data, 4520 tons of oleaster production was carried out in a 271-decare area in 2016. In 2016, there were a total of 343635 oleaster trees in Turkey, which included 304312 fruit bearing trees and 39323 trees not of fruit-bearing age (Tuik 2016).

This study determined for the first time the morphological characteristics of oleaster wood together with the cell wall components and solubility values of oleaster wood and bark obtained from the Konya, Balikesir and Çankiri regions of Turkey.

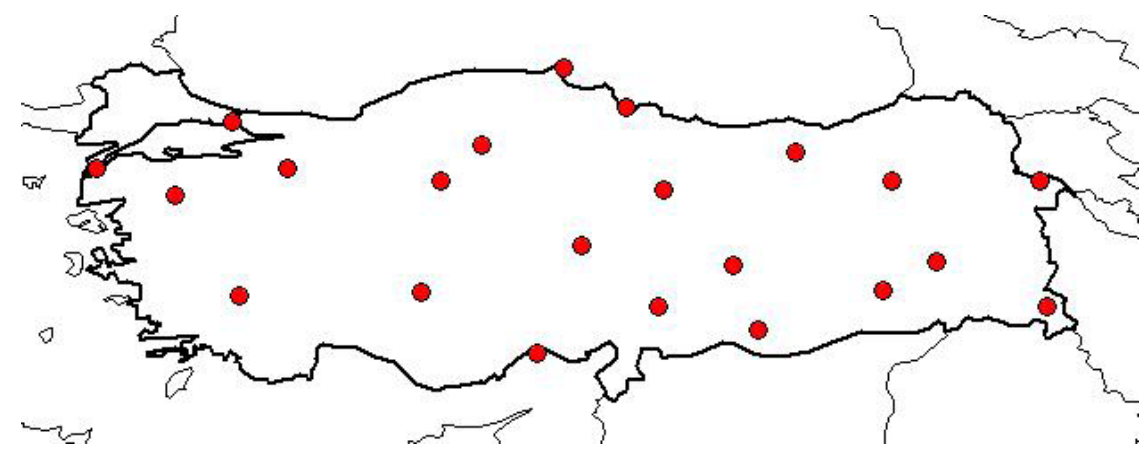

Figure 1: Distribution of oleaster (Elaeagnus angustifolia) in Turkey.

\section{MATERIALS AND METHODS}

The wood and bark samples of oleaster (Elaeagnus angustifolia L.) used in the study, were taken from three different regions of Turkey having different climatic conditions and different elevations. The location, elevation and mean rainfall values of these regions are given in Table 1. 
Table 1: Location, elevation and mean rainfall values of the regions chosen for the study.

\begin{tabular}{|c|c|c|c|c|}
\hline Years & $\begin{array}{c}\text { Elevation } \\
(\mathbf{m})\end{array}$ & Location & $\begin{array}{c}\text { Mean Rainfall } \\
(\mathbf{m m})\end{array}$ & \multicolumn{1}{c|}{ Source } \\
\hline $1964-2010$ & 970 & Konya-Karapinar & 283 & $\begin{array}{l}\text { General Directora- } \\
\text { te of Meteorology } \\
(\text { MGM, 2010) }\end{array}$ \\
\hline $1930-2010$ & 730 & Çankiri-Ilgaz & 484 & $\begin{array}{l}\text { General Directora- } \\
\text { te of Meteorology } \\
\text { (MGM, 2010) }\end{array}$ \\
\hline $1970-2010$ & 30 & Balikesir-Edremit & 707 & $\begin{array}{l}\text { General Directora- } \\
\text { te of Meteorology } \\
\text { (MGM, 2010) }\end{array}$ \\
\hline
\end{tabular}

Samples from cut trees were collected according to TAPPI T $257 \mathrm{~cm}-85$ (1985) standards. The wood and bark specimens, after being reduced to small particles, were ground separately as heartwood, sapwood, inner bark (phloem) and outer bark (rhylidome) in a Wiley mill. After the ground wood and bark samples were passed through a 40-mesh sieve, the samples remaining in a 60-mesh sieve were used for chemical analyses.

\section{Chemical analyses}

Experimental samples were subjected to the following analyses:

- Holocellulose Assay: Wise and Jahn chlorite method (Wise and Jahn 1952)

- $\quad$ Lignin Assay: TAPPI T 222 om-88 (1988)

- Alfa Cellulose Assay: TAPPI T 203 OS-71 (1975)

- $\quad$ Ash Assay : TAPPI T 211 om-85 (1992)

- Alcohol Solubility Rate: TAPPI T 204 om-88 (2002)

- Cold and Hot Water Solubility Rate: TAPPI T 207 om-99 (2002)

- $\quad 1 \% \mathrm{NaOH}$ Solubility Rate: TAPPI T 212 om-98 (2002)

In determining the major components of the cell wall and analyzing the solubility, three replicates were conducted for each experiment.

\section{Analytical methods (Sugar analysis)}

The sugar analysis of the oleaster wood samples was determined according to the NREL method (Laboratory Analytical Procedures (LAP) from the National Renewable Energy Laboratory) (Sluiter et al. 2008). Prior to the high performance liquid chromatography (HPLC) sugar analysis, acid hydrolysates containing monosaccharides were brought to $\mathrm{pH} 7$ level with calcium carbonate so that the $\mathrm{pH}$-gradient column was not damaged. The HPLC analyses were performed with an Agilent 1200 system and a refractive index detector (RID) connected to this system. The injection volume was applied as $20 \mu \mathrm{L} ; 5 \mathrm{M} \mathrm{H}_{2} \mathrm{SO}_{4}$ was used as the mobile phase and the flow rate was determined to be $0,5 / \mathrm{min}$. A Shodex SH1011 No: H810110 column at a temperature of $60{ }^{\circ} \mathrm{C}$ was used to carry out the chromatographic separation of the sugars (cellobiose, glucose and xylose). 


\section{Morphological methods}

The chlorite method was used for maceration of the oleaster wood fibers supplied from the different regions (Wise and Jahn 1952). The fibers were thoroughly washed, put in a mixer and mixed for 3 min. The fiber suspension was then filtered through a filter paper in a Buchner funnel. The fibers remaining on the filter paper were placed in small tubes and glycerin was added to them. In addition, in order to obtain better images on the microscope, the fibers were stained with safranin and preserved. An Olympus CX21 light microscope was used to characterize the fibers. Fiber length was measured via the $10 \times$ objective lens, while fiber width, lumen width and double wall thickness were measured via the $40 \times$ lens. A total of 40 measurements were made from each sample. The criteria used in evaluating the fibers in terms of papermaking are given below.

- $\quad$ Elasticity coefficient $(\%)$ : (Lumen diameter $\div$ Fiber diameter $) \times 100$

- $\quad$ Felting rate: Fiber length $\div$ Fiber diameter

- Runkel index: Cell wall thickness $\div$ Lumen diameter

- $\quad$ Rigidity coefficient (\%): (Cell wall thickness $\div$ Fiber diameter $) \times 100$

- $\quad$ F ratio $(\%)$ : (Fiber length $\div$ Cell wall thickness $) \times 100$

- $\quad$ Muhlstep classification: (Cell wall area $\div$ Fiber cross-sectional area) $\times 100$

The mean values and standard deviations of the obtained data were then calculated.

\section{RESULTS AND DISCUSSION}

The chemical components and the solubility values of the trunk wood and bark of the oleaster tree are shown in Table 2.

Table 2: Quantity and solubility values of the chemical components of the hardwood, sapwood, inner bark and outer bark of the oleaster.

\begin{tabular}{|c|c|c|c|c|c|c|c|c|c|c|c|c|}
\hline \multirow{3}{*}{\begin{tabular}{|c|}
$\begin{array}{c}\text { Precipitation } \\
\text { Type }\end{array}$ \\
$\begin{array}{c}\text { Elevation } \\
(\mathrm{m})\end{array}$ \\
$\begin{array}{c}\text { Raw } \\
\text { materials }\end{array}$ \\
\end{tabular}} & \multicolumn{4}{|c|}{ Arid Region } & \multicolumn{4}{|c|}{$\begin{array}{c}\text { Moderate Precipitation } \\
\text { Region }\end{array}$} & \multicolumn{4}{|c|}{ Wet Region } \\
\hline & \multicolumn{4}{|c|}{$970 \mathrm{~m}$} & \multicolumn{4}{|c|}{$730 \mathrm{~m}$} & \multicolumn{4}{|c|}{$30 \mathrm{~m}$} \\
\hline & $\begin{array}{c}\text { KH } \\
\text { W }\end{array}$ & KSW & KIB & КOB & $\begin{array}{l}\text { ÇH } \\
\text { W }\end{array}$ & ÇSW & ÇIB & ÇOB & $\begin{array}{l}\text { BH } \\
\text { W }\end{array}$ & BSW & BIB & ВОВ \\
\hline Holocellulose & $\begin{array}{l}80,2 \pm \\
0,22\end{array}$ & $\begin{array}{l}80,8 \pm \\
0,19\end{array}$ & $\begin{array}{l}70,8 \pm \\
0,10\end{array}$ & $\begin{array}{l}61,3 \pm \\
0,77\end{array}$ & $\begin{array}{l}84,9 \pm \\
0,49\end{array}$ & $\begin{array}{l}84,1 \pm \\
0,08\end{array}$ & $\begin{array}{l}67,9 \pm \\
1,17\end{array}$ & $\begin{array}{l}61,0 \pm \\
0,11\end{array}$ & $\begin{array}{l}82,0 \pm \\
0,36\end{array}$ & $\begin{array}{l}80,9 \pm \\
0,16\end{array}$ & $\begin{array}{l}56,1 \pm \\
0,64\end{array}$ & $\begin{array}{l}54,4 \pm \\
0,32\end{array}$ \\
\hline $\begin{array}{c}\text { Alfa } \\
\text { Cellulose }\end{array}$ & $\begin{array}{l}50,3 \pm \\
0,67\end{array}$ & $\begin{array}{l}48,6 \pm \\
0,32\end{array}$ & $\begin{array}{l}44,6 \pm \\
0,96\end{array}$ & $\begin{array}{l}37,0 \pm \\
0,09\end{array}$ & $\begin{array}{l}49,4 \pm \\
0,11\end{array}$ & $\begin{array}{l}51,8 \pm \\
0,40\end{array}$ & $\begin{array}{l}43,7 \pm \\
0,27\end{array}$ & $\begin{array}{l}37,1 \pm \\
0,02\end{array}$ & $\begin{array}{l}52,3 \pm \\
0,76\end{array}$ & $\begin{array}{l}50,3 \pm \\
0,72\end{array}$ & $\begin{array}{l}30,9 \pm \\
0,57\end{array}$ & $\begin{array}{l}26, \mathrm{l} \pm \\
1,07\end{array}$ \\
\hline Lignin & $\begin{array}{l}22,8 \pm \\
0,19\end{array}$ & $\begin{array}{l}23,2 \pm \\
0,34\end{array}$ & $\begin{array}{l}19,8 \pm \\
0,33\end{array}$ & $\begin{array}{l}36,7 \pm \\
0,87\end{array}$ & $\begin{array}{l}20,2 \pm \\
0,11\end{array}$ & $\begin{array}{l}21,3 \pm \\
0,03\end{array}$ & $\begin{array}{l}22,7 \pm \\
0,44\end{array}$ & $\begin{array}{l}27,3 \pm \\
0,91\end{array}$ & $\begin{array}{l}22,9 \pm \\
0,14\end{array}$ & $\begin{array}{l}24,0 \pm \\
0,43\end{array}$ & $\begin{array}{l}19,6 \pm \\
0,24\end{array}$ & $\begin{array}{l}44,2 \pm \\
0,70\end{array}$ \\
\hline Ash & $\begin{array}{l}0,6 \pm \\
0,03\end{array}$ & $\begin{array}{l}0,7 \pm \\
0,05\end{array}$ & $\begin{array}{l}2,1 \pm \\
0,04\end{array}$ & $\begin{array}{l}2,5 \pm \\
0,03\end{array}$ & $\begin{array}{l}0,5 \pm \\
0,03\end{array}$ & $\begin{array}{l}0,7 \pm \\
0,12\end{array}$ & $\begin{array}{l}2,0 \pm \\
0,11\end{array}$ & $\begin{array}{l}7,0 \pm \\
0,04\end{array}$ & $\begin{array}{l}0,4 \pm \\
0,01\end{array}$ & $\begin{array}{l}0,7 \pm \\
0,05\end{array}$ & $\begin{array}{l}3,3 \pm \\
0,04\end{array}$ & $\begin{array}{l}4,4 \pm \\
0,06\end{array}$ \\
\hline $\begin{array}{c}\text { Cold } \\
\text { Water }\end{array}$ & $\begin{array}{l}2,5 \pm \\
0,10\end{array}$ & $\begin{array}{l}3,2 \pm \\
0,05\end{array}$ & $\begin{array}{l}15,3 \pm \\
0,28\end{array}$ & $\begin{array}{l}6,8 \pm \\
0,20\end{array}$ & $\begin{array}{l}4,4 \pm \\
0,07\end{array}$ & $\begin{array}{l}6,1 \pm \\
0,13\end{array}$ & $\begin{array}{l}11,8 \pm \\
0,11\end{array}$ & $\begin{array}{l}13,5 \pm \\
0,14\end{array}$ & $\begin{array}{l}2,5 \pm \\
0,08\end{array}$ & $\begin{array}{l}4,3 \pm \\
0,10\end{array}$ & $\begin{array}{l}25,7 \pm \\
0,16\end{array}$ & $\begin{array}{l}16,4 \pm \\
0,22\end{array}$ \\
\hline Hot Water & $\begin{array}{l}2,5 \pm \\
0,07\end{array}$ & $\begin{array}{l}3,7 \pm \\
0,05\end{array}$ & $\begin{array}{l}16,7 \pm \\
0,16\end{array}$ & $\begin{array}{l}8,5 \pm \\
0,08\end{array}$ & $\begin{array}{l}4,3 \pm \\
0,25 \\
\end{array}$ & $\begin{array}{l}6,0 \pm \\
0,08\end{array}$ & $\begin{array}{l}15,5 \pm \\
0,09\end{array}$ & $\begin{array}{l}17,7 \pm \\
0,11\end{array}$ & $\begin{array}{l}3,5 \pm \\
0,03 \\
\end{array}$ & $\begin{array}{l}5,2 \pm \\
0,02 \\
\end{array}$ & $\begin{array}{l}27,7 \pm \\
0,34\end{array}$ & $\begin{array}{l}18,3 \pm \\
0,09\end{array}$ \\
\hline $\begin{array}{l}\text { Ethyl- } \\
\text { Alcohol }\end{array}$ & $\begin{array}{l}2,6 \pm \\
0,08\end{array}$ & $\begin{array}{l}2,3 \pm \\
0,06\end{array}$ & $\begin{array}{l}13,7 \pm \\
0,11\end{array}$ & $\begin{array}{l}11,0 \pm \\
0,17\end{array}$ & $\begin{array}{l}4,6 \pm \\
0,10\end{array}$ & $\begin{array}{l}4,0 \pm \\
0,12\end{array}$ & $\begin{array}{l}11,8 \pm \\
0,25\end{array}$ & $\begin{array}{l}13,3 \pm \\
0,04\end{array}$ & $\begin{array}{l}3,6 \pm \\
0,30\end{array}$ & $\begin{array}{l}4,3 \pm \\
0,08\end{array}$ & $\begin{array}{l}30,6 \pm \\
0,48\end{array}$ & $\begin{array}{l}25,4 \pm \\
0,91\end{array}$ \\
\hline $1 \% \mathrm{NaOH}$ & $\begin{array}{l}31,6 \pm \\
0,21\end{array}$ & $\begin{array}{l}12,7 \pm \\
0,14\end{array}$ & $\begin{array}{l}50,8 \pm \\
0,94\end{array}$ & $\begin{array}{l}57,7 \pm \\
0,90\end{array}$ & $\begin{array}{l}32,4 \pm \\
0,04\end{array}$ & $\begin{array}{l}31,9 \pm \\
0,11\end{array}$ & $\begin{array}{l}52,4 \pm \\
0,06\end{array}$ & $\begin{array}{l}62,7 \pm \\
0,50\end{array}$ & $\begin{array}{l}14,1 \pm \\
0,17\end{array}$ & $\begin{array}{l}14,7 \pm \\
0,14\end{array}$ & $\begin{array}{l}51,1 \pm \\
0,02\end{array}$ & $\begin{array}{l}78,0 \pm \\
0,76\end{array}$ \\
\hline
\end{tabular}

士: Standard deviation (KHW: Konya Heartwood, KSW: Konya Sapwood, KIB: Konya Inner Bark, KOB: Konya Outer Bark; ÇHW: Çankiri Heartwood, ÇSW: Çankiri Sapwood, ÇIB: Çankiri Inner Bark, ÇOB: Çankiri Outer Bark; BHW: Balikesir Heartwood, BSW: Balikesir Sapwood, BIB: Balikesir Inner Bark, BOB: Balikesir Outer Bark). 
As shown in Table 2, the highest amount (84,9\%) of holocellulose was found in the oleaster wood samples from the Çankiri region, while the highest amounts of alpha cellulose $(52,3 \%)$ and lignin $(24,0 \%)$ were found in the wood samples taken from the Balikesir region, which is a wet precipitation zone. All the solubility values of the wood samples taken from the Çankiri region, including that of the $1 \% \mathrm{NaOH}$, were found to be the highest.

The low temperature in the high regions leads to the narrowing of the annual ring, the excessive rainfall in arid regions causes the annual ring to expand. The rate of participation in summer wood increases as annual rings of wood are shrinking, decreasing as they expand (Bozkurt and Erdin 1997). Despite the fact that the amount of rainfall in the Çankiri region is moderate, the air temperatures are low due to the high region and the continental climate. Due to the reasons explained above, the annual ring structure is narrow in the samples taken from the Çankiri region and therefore the participation rate of summer wood is high. Because of the thicker cell wall in the summer wood, the amount of cellulose is high, the lignin rich middle lamella is thinner, so the amount of lignin is less (Hafizoğlu and Deniz 2011). Because of this reason, the amount of holocellulose is high and the amount of lignin is considered to be low compared to other regions, as the rate of summer wood participation is high in samples taken from Çankiri region. In the samples taken from the Balikesir region, it is thought that the annual ring structure may be wide due to the high amount of precipitation and the favorable conditions of the temperature. The rate of springwood increases as the annual ring expands and the amount of lignin increases as the springwood rate increases. For these reasons, it is considered that the amount of lignin is high in the samples taken from Balikesir region. The $1 \% \mathrm{NaOH}$ solubility gives us information on the amount of hemicellulose in the wood. Since the solubility of $1 \% \mathrm{NaOH}$ in the samples taken from the Balikesir region is lower than the other regions, it is thought that the amount of alpha cellulose is high. Cell wall thickness in annual ring is higher in summer wood than spring wood (Bozkurt and Erdin 1997). In the samples taken from the Çankiri region, it is considered that all of the solubility values are high due to the high share of summer wood.

According to the literature, the amounts of holocellulose and alpha cellulose ratios found in the oleaster tree wood were quite high in terms of the wood of leafy tree species grown in Turkey. On the other hand, the amount of lignin was found to be close to that of other leafy tree species. The solubility value results for the wood were close to the results of previously reviewed literature. The results of this study are supported by those of Akgül (2016), who found the percentages of holocellulose, alpha cellulose, lignin, ash and alcohol-benzene, hot water, cold water and $1 \% \mathrm{NaOH}$ solubility to be, respectively, $68,8 \% ; 43,5 \% ; 23,6 \% ; 0,3 \% ; 7,42 \%$; $7,40 \% ; 6,30 \%$ and $28,5 \%$.

When the bark extracts were examined, the highest amounts of holocellulose $(70,8 \%)$ and alpha cellulose $(44,6 \%)$ were found in inner bark (phloem) samples taken from the Konya region, while the highest lignin amounts $(44,2 \%)$ were found in the outer bark (rhylidome) samples taken from the Balikesir region. Akgül and Üner (2008) found the amount of holocellulose and lignin in the inner and outer bark of the ostrya (hophornbeam) tree to be $71,2 \%$ and $41,2 \%$ respectively. The amount of alpha cellulose was observed to be quite high when the bark studies were examined. The bark solubility values were highest in the samples taken from the Balikesir region, which is a wet precipitation zone. Water solubility and alcohol solubility were found to be higher in the inner bark samples, whereas $1 \% \mathrm{NaOH}$ solubility was higher in the outer bark samples. Balaban and Uçar (2001) found the alcohol-benzene solubility of the kasnak oak tree to be $14,6 \%$. In this study, the alcohol solubility in the samples taken from Balikesir region was found to be $30,6 \%$. This value is significant for the amount of bark extractive substance.

Due to the aridness of the Konya region, phloem cells produced by the cambium layer are thought to have thicker walls. Therefore, it is estimated that the amount of holocellulose and alpha cellulose in the inner shell samples taken from the Konya region is high. The reason for the high amount of lignin in the samples taken from the Balikesir region is thought to be caused by the high resolution values in this region. Since the solubility values in the shell vary according to many different factors, it is very hard to say something about the very high shell resolution values in Balikesir region. 


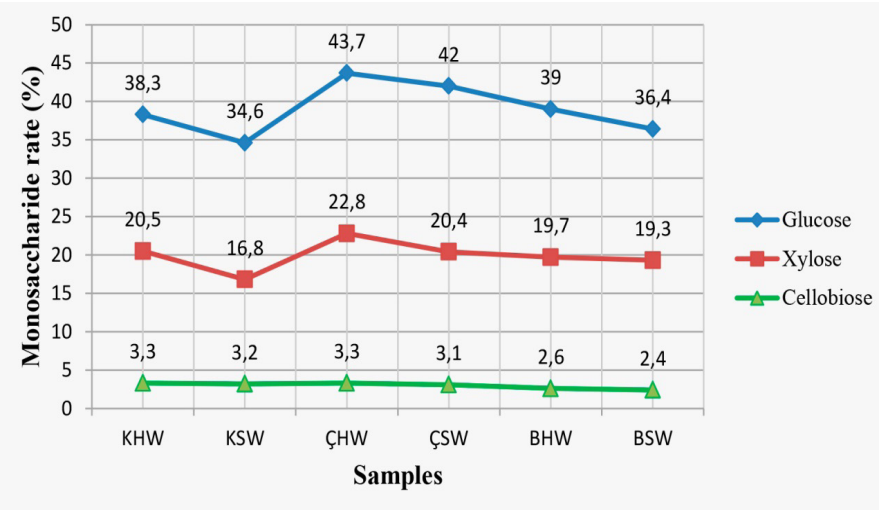

Figure 2: Oleaster tree heartwood and sapwood sugar analysis results (\%) (KHW: Konya heartwood, KSW: Konya sapwood, ÇHW: Çankiri heartwood, ÇSW: Çankiri sapwood, BHW: Balikesir heartwood, BSW: Balikesir sapwood).

The sugar analysis of the oleaster tree shows that the highest glucose and xylose ratios were found in the samples of heartwood taken from Çankiri region, as seen in Figure 2. The Holocellulose ratio (Table 2) was found to be equivalent to the glucose and xylose ratios and to be the highest in the heartwood samples taken from the Çankiri region. No significant differences were observed in the cellobiose ratio among the regions. As seen in Figure 2, glucose and xylose ratios for heartwood were higher than those for sapwood in in all regional samples. It is thought that the ratio of glucose and xylose in the Çankiri region is higher than in other regions due to the high rate of summer wood in the annual ring. Balaban et al. (1999), in their study, found the percentage of xylose, arabinose, mannose, glucose and galactose in kasnak oak (Quercus vulcanica Boiss) heartwood to be $19,76 \% ; 0,77 \% ; 2,50 \% ; 48,82 \% ; 0,91 \%$, and in the sapwood $20,36 \% ; 0,79 \% ; 2,14 \% ; 49,40 \%$ and $0,89 \%$, respectively. Timell (1982) reported the xylose, arabinose, mannose, glucose and galactose ratios to be $19,05 \% ; 0,5 \% ; 2,1 \% ; 46 \%$ and $1,2 \%$ in American beech (Fagus grandifolia) trunk wood. The glucose rates in the samples taken from the Çankiri region were close to those found in the literature, while the glucose in the samples taken from Balikesir and Konya were found to be very low compared to the literature. According to the literature, the xylose ratio was high in Çankiri heartwood, low in Konya sapwood and comparable in the other wood samples.

Table 3: Fiber morphology results of oleaster wood.

\begin{tabular}{|c|c|c|c|c|c|c|c|c|c|c|c|c|}
\hline & \multicolumn{3}{|c|}{ Fiber length (mm) } & \multicolumn{3}{|c|}{ Fiber width $(\mu \mathrm{m})$} & \multicolumn{3}{|c|}{ Lumen diameter $(\mu \mathrm{m})$} & \multicolumn{3}{|c|}{$\begin{array}{l}\text { Double wall thickness } \\
\qquad(\mu \mathrm{m})\end{array}$} \\
\hline & $\mathbf{K}$ & B & Ç & $\mathbf{K}$ & B & Ç & $\mathbf{K}$ & B & Ç & $\mathbf{K}$ & B & Ç \\
\hline Average & 0,87 & 0,96 & 0,93 & 23,77 & 24,33 & 22,93 & 12,87 & 13,27 & 11,67 & 9,40 & 9,67 & 8,17 \\
\hline Std, Dev & 0,67 & 0,92 & 0,85 & 1,39 & 2,39 & 2,17 & 1,71 & 2,28 & 2,11 & 0,79 & 0,51 & 0,75 \\
\hline $\begin{array}{c}\text { Fiber } \\
\text { dimensions } \\
\text { of leafy } \\
\text { trees found } \\
\text { in Turkey } \\
\text { (Alkan et al. } \\
\text { 2003) }\end{array}$ & \multicolumn{3}{|c|}{$0,73-1,47$} & \multicolumn{3}{|c|}{$19,5-27,72$} & \multicolumn{3}{|c|}{$4,75-17,7$} & \multicolumn{3}{|c|}{$7-17,76$} \\
\hline
\end{tabular}

K: Konya, B: Balikesir, Ç: Çankiri.

Table 3 shows that, although the oleaster tree wood fiber length, fiber width, lumen diameter and double wall thickness were highest in the samples taken from the Balikesir region, the differences among the regions 
were not significant. All data for fiber morphology were obtained from Alkan et al. (2003), who found that "some morphological tree angiospermae taxa in Turkey are among the data obtained in the study of fiber morphology." According to the data obtained, oleaster tree wood displays average lumen diameters and short, thin-walled fibers.

Table 4: The ratios between oleaster tree fiber sizes.

\begin{tabular}{|c|c|c|c|c|c|c|}
\hline & $\begin{array}{l}\text { Elasti- } \\
\text { city } \\
\text { Rate }\end{array}$ & $\begin{array}{c}\text { Felting } \\
\text { Rate }\end{array}$ & $\begin{array}{l}\text { Runkel } \\
\text { Classi- } \\
\text { fication }\end{array}$ & $\begin{array}{c}\text { Rigidity } \\
\text { Coeffi- } \\
\text { cient }\end{array}$ & $\begin{array}{c}\text { Muhlstep } \\
\text { Classifica- } \\
\text { tion }\end{array}$ & F-Factor \\
\hline Konya & 54,14 & 36,60 & 0,73 & 18,26 & 70,69 & 185,11 \\
\hline Balikesir & 54,54 & 39,45 & 0,72 & 18,22 & 70,26 & 198,35 \\
\hline Çankiri & 50,89 & 40,55 & 0,7 & 17,5 & 74,1 & 221,95 \\
\hline Average & 53,19 & 39,87 & 0,72 & 17,99 & 70,45 & 201,80 \\
\hline $\begin{array}{l}\text { Data for leafy trees } \\
\text { found in Turkey } \\
\text { (Alkan } \text { et al. } 2003 \text { ) }\end{array}$ & $\begin{array}{c}24,35- \\
71,28\end{array}$ & $\begin{array}{c}34,49- \\
63,86\end{array}$ & $0,4-3,1$ & $14-37$ & $55,37-94,06$ & $147,01-303,68$ \\
\hline
\end{tabular}

Fibers with an elasticity ratio of 50-75 are considered flexible fibers and are important for papermaking (Kirci 2000). According to Table 4, the average elasticity ratio of the oleaster tree wood is 53,19 which is very suitable for paper production. A high felting ratio of $70 \%$ indicates that the paper strength and resistance to tearing, breaking and double folding will be high (Kirci 2000, Bektaş et al. 1999, Akgül and Tozluoğlu 2009). The average felting rate of the oleaster tree wood was found to be 39,87 signifying that the resistance values of the paper to be obtained would be low. The Runkel classification was an average of 0,72 and this low value of less than 1 is a sign that the fibers are thin-walled and would be considered suitable for paper production (Bostanci 1980). A high value for the coefficient of rigidity affects the tearing, breaking and double-folding resistance of the paper in a negative way. The rigidity coefficient of the oleaster wood was 17,99 which was determined to be within the rigidity coefficient values of the leafy trees in Turkey. The Muhlstep classification gives information about the physical properties of paper. The oleaster Muhlstep classification was found to be 70,45 on average and was determined to be within the Muhlstep classification values of the leafy trees in Turkey. The low Runkel ratio of less than 1 indicated that the oleaster tree fibers were thin-walled, making it possible to reach desired physical property values for the paper to be produced. The F-factor indicates the flexibility of the paper to be produced. The F-factor of oleaster tree wood was found to be 201,80 which is within the F-factor values of the leafy trees in Turkey.

Table 5: Relations between morphological properties of fiber cells and physical resistance properties of paper.

\begin{tabular}{|l|c|c|c|c|}
\hline Relationships & $\begin{array}{c}\text { Burst } \\
\text { Resistance }\end{array}$ & $\begin{array}{c}\text { Tear } \\
\text { Resistance }\end{array}$ & $\begin{array}{c}\text { Double } \\
\text { Fold } \\
\text { Resistance }\end{array}$ & $\begin{array}{c}\text { Paper } \\
\text { Density } \\
(*)\end{array}$ \\
\hline With increase of fiber length & + & ++ & + & - \\
\hline $\begin{array}{l}\text { With increase of cell wall } \\
\text { thickness }\end{array}$ & - & + & +- & ++ \\
\hline $\begin{array}{l}\text { With decrease of cell wall } \\
\text { thickness }\end{array}$ & + & - & + & \\
\hline $\begin{array}{l}\text { With increase of fiber } \\
\text { length/fiber width }\end{array}$ & & + & + & - \\
\hline With increase of fiber curl & - & + & + \\
\hline
\end{tabular}

(*): Porosity, air permeability, water retention capacity and volume are inversely proportional to density.

$(+)$ : Determined to have a positive effect. $(++)$ : Absolutely positive effect. (-): Determined to have a negative effect. $(--)$ : Absolute negative effect. (Bostanci 1980, Bektaş et al. 1999). 
According to Table 5, as the fiber cell wall thickness decreases, the bursting, double-folding resistance and density of the paper to be produced increase, while the tear resistance decreases. As the fiber length decreases, the density of the paper increases, but the resistance values decrease.

\section{CONCLUSIONS}

The data obtained from the study revealed no significant differences in the heartwood and sapwood components of the oleaster tree samples from different elevations and precipitation zones. However, in the bark samples, it was determined that the inner bark exhibited a more woody structure and that the amount of holocellulose was higher in the oleaster trees growing in arid regions at high elevation, while the amount of lignin was higher in the oleaster trees growing in wet areas near sea level. The alcohol-benzene solubility of the oleaster tree bark was found to be $30,6 \%$. This value is significantly higher than the alcohol-benzene solubility values of the bark of other leafy trees. One thing that should be emphasized is that in future studies on the bark of the oleaster tree, the extractive substances in the bark need to be identified. Thus, in addition to the traditional products and uses of the bark, the possibilities will be put forward for utilization of the benefits of extractive substances found in the trunk as well.

No differences were found in the fiber characteristics (fiber length, fiber width, lumen diameter and double wall thickness) of the wood of the oleaster trees grown in the different regions. Moreover, the data obtained in the study fell within the values of fiber morphology detected in the leafy trees in Turkey. When evaluated in terms of papermaking, the fiber morphology of the oleaster wood was generally found to be suitable for paper production; however, because of its short fiber length, the strength values of the paper would be low. In spite of this, the fact that the oleaster tree wood from all regions had a holocellulose value of over $80 \%$ is very important for papermaking in terms of yield.

The challenge in the forest products industry today and to be experienced in the future is one of procuring raw material. This highlights the need to investigate all types of novel raw materials available for possible utilization.

\section{REFERENCES}

Akgül, M.; Üner, B. 2008. The Chemical Composition of Wood and Bark of Ostrya carpinifolia Scop. 3rd. International Sci. Conf. FORTECHENVI 2008, Prague, Czech Republic, May 26-30, 215-218.

Akgül, M.; Tozluoğlu, A. 2009. Some Chemical and Morphological Properties of Juvenille Woods from Beech (Fagus orientalis L.) and Pine (Pinus nigra A.) plantations. Trends in Applied Sciences Research 4(2):116-125.

Akgül, M. 2016. The Chemical Components in Wood and Bark of Turkish Hazel (Corylus colurna L.). International Journal of Scientific and Technological Research 2(1):63-70.

Alkan, C.; Eroğlu, H.; Yaman, B. 2003. Fiber morphology of some natural angiospermae taxa in Turkey. Journal of the Bartin Faculty of Forestry 5(5): 102-108.

Anonymous 2007. Rüzgâr Erozyonu. Tarım Kütüphanesi. < <http://www.tarimkutuphanesi.com/RÜZGÂR/EROZYONU/00156.html>.

Balaban, M.; Yilgör, N.; Strobel, C. 1999. Chemical characteristics of endemic oak-wood Quercus vulcanica Boiss. Holz als Roh-und Werkstoff 57(2): 152-153. https://doi.org/10.1007/s001070050032.

Balaban, M.; Uçar, G. 2001. Extractives and structural components in wood an bark of endemic Oak Quercus vulcanica Boiss. Holzforschung 55(5): 478-486. https://doi.org/10.1515/HF.2001.079.

Bektaş, I.; Tutuş, A.; Eroğlu, H. 1999. A study of the suitability of Calabrian pine (Pinus brutia Ten.) for pulp and paper manufacture. Turkish Journal of Agriculture and Forestry 23(EK3): 589-598. 
Biermann, C.J. 1993. Wood and fiber Fundamentals. Essentials of pulping and papermaking. Academic press: London, pp.13-54.

Bostanci, S. 1980. Evaluation Possibilities of Sunflower (Helianthus annuus L.) Stems and Roots in Paper Industry. Associate Professor Thesis, K.T.U. Forest Faculty, Trabzon, p. 159.

Bozkurt, Y.; Erdin, N. 1997. Textbook of Wood Technology. İ.U. Forest Faculty Forest Industry Engineering: Istanbul, 363p.

Cadania, E.; Munoz, L.; Fernández de Dimón, B.; García-Vallejo, M. 2001. Changes in low molecular weight phenolic compounds in Spanish, French and American Oak woods during natural seasoning and toasting. Journal of Agricultural Food Chemistry 49(4):1790-1798. https://doi.org/10.1021/jf0006168.

Carrol, R.B.; Morehart, A.L.; Stuart, M. 1976. Phomopsis canker of Russian-olive in Delaware. Plant Dis Rep 60:787-788.

Cunha-Queda, A.C.; Riberira, H.M.; Ramos, A.; Cabral, F. 2007. Study of biochemical and microbiological parameters during composting of pine and eucalyptus bark. Bioresource Technology 98(17): 32133220. https://doi.org/10.1016/j.biortech.2006.07.006. $197 \mathrm{p}$.

Hafizoğlu, H.; Deniz, İ. 2011. Wood Chemistry Lecture Notes Book. K.T.U. Forest Faculty, Trabzon,

Kähkonen, M.P.; Hapia, A.I.; Vuorela, H.J.; Rauha, J.P.; Pihlaja, K.; Kujala, T.S.; Heinonen, M. 1999. Antioxidant activity of plant extracts containing phenolic compounds. Journal of Agricultural Food Chemistry 47(10):3954-3962. https://doi.org/10.1021/jf9901461.

Karonen, M.; Hämäläinen, M.; Nieminen, R.; Klika, D.K.; Laponen, J.; Ocharenko, V.; Mailainen, E.; Pihlaja, K. 2004. Phenolic extractives from the bark of Pinussylvestris L. and their effects on inflammatory mediators nitric oxide and Prostaglandin E2. Journal of Agricultural Food Chemistry 52(25):7532-7540.

MGM. 2010. General Directorate of Meteorology climate data. www.mgm.gov.tr 274 .

Kirci, H. 2000. Paper Pulp Industries Lecture Notes. K.T.U. Forest Faculty. Edition No:63. Trabzon.

Krupinsky, J.M.; Frank, A.B. 1986. Effects of water stress on Tubercularia canker of Russian olive. Great Plains Agriculture [i.e. Agricultural] Council publication 117:171-172.

Peterson, G.W. 1976. Disease of Russian-olive caused by Botryodiplodia theobromae. Plant Dis Rep 60:490- 494 .

Pietta, P. 2000. Flavanoids as antioxidants. Journal of Natural Products 63(7):1035-1042. https://doi. org/10.1021/np9904509.

Sluiter, A.; Hames, B.; Ruiz, R.; Scarlata, C.; Sluiter, J.; Templeton, D.; Crocker, D. 2008. Determination of structural carbonhydrates and ligninin biomass. Technical report NRELL/TP-510-42618, National Renewable Energy Laboratory, Golden, Colarado.

Tan, Y.M.; Yu, R.; Pezzuto, J.M. 2003. Betulinic acid-induced programmed cell death in human melanoma cell involves mitogen-activated protein kinase activation. Clinical Cancer Research 9(7):2866-2875.

Timell, T.E. 1982. Recent progress in the chemistry and topochemistry of compression wood. Wood and Science Technology 16(2): 83-122. https://doi.org/10.1007/BF00351097.

TAPPI. 1985. Sampling and preparing wood for analysis. TAPPI T257 cm-85, 1985. TAPPI Press: Atlanta, Ga, USA.

TAPPI. 1988. Acid-insoluble lignin in wood and pulp. TAPPI Method T 222 om-88, 1988. TAPPI Press: Atlanta, Ga, USA. 
TAPPI. 1975. Alpha, beta and gamma cellulose in pulp. TAPPI T 203 os-71, 1975. TAPPI Press: Atlanta, Ga, USA.

TAPPI. 1992. Ash in Wood and Pulp, Tappi Test Methods. TAPPI T 211 om-85, 1992. TAPPIPress:Atlanta, Ga, USA.

TAPPI. 2002. Alcohol-benzene Solubility of Wood. TAPPI T 204 om-88, 2002. TAPPI Press : Atlanta, $\mathrm{Ga}$, USA.

TAPPI. 2002. Water Solubility of Wood and Pulp. TAPPI T 207 cm-99, 2002. TAPPI Press: Atlanta, Ga, USA.

TAPPI. 2002. One Percent Sodium Hydroxide Solubility of Wood and Pulp. TAPPI T 212 om-98, 2002. TAPPI Press:Atlanta, Ga, USA.

Tuik. 2016. Bitkisel Üretim İstatistikleri. <https://biruni.tuik.gov.tr/bitkiselapp/bitkisel.zul>

Wilför, S.M.; Ahotupo, M.O.; Hemming, J.E.; Reunanen, M.H.; Eklund, P.C.; Sjöhölm, R.E.; Eckerman, C.S.; Pohjamo, S.P.; Holmbom, B.R. 2003. Antioxidant activity of knot wood extractives and phenolic compounds of selected tree species. Journal of Agricultural Food Chemistry 51(26):7600-7606. https:// doi.org/10.1021/jf030445h.

Wise, L.E.; Jahn, E.C. 1952. Wood Chemistry. Second Edition. Reinhold Publishing Corporation: New York, USA, 1344p. 